\title{
Corporate E-Learning Strategy
}

\author{
doi:10.3991/ijac.v3i4.1462 \\ Sergey Sitnikov, Boris Kruk, Olga Zhuravleva and Natalia Chupakhina \\ Siberian State University of Telecommunications and Information Sciences, Novosibirsk, Russia
}

\begin{abstract}
Not th e leas $t$ factor, when lau nching th e corp orate training, is str ategy dete rmination. On the one hand, an educational institution has to follow the mar ket and be able to s atisfy the demands of corporate clients and companies. It is a s o called market adaptation. However, th is approach implies a number of shortcomings. An excessive interest in mar ket ad aptation may lead to lop -sided development of training process: the educational institution turns into the mirro $r$ reflecting th e co rporation opinion and moulds its vision of the future only due to demands of the corporation. In contrast to th at, there is an approach when the e ducational institution se arches appr opriate de velopment directions independently, thereby taking the lead over corporations' de mands an d competitors. Suc h e ducational institution te nds to e xcel in change $s, w$ hich happe $n$ in the market, and to make the strategy satisfy future interests and demands of the corporation.
\end{abstract}

Traditional tra ining is grou nded on the disciplinary approach to tr aining. How ever, today busine ss faces complex problems which solution $c$ an be found at the joints of disciplines and act ivities. Compan ies need mul tidisciplinary approaches to training. It is ve ry impor tant to ke ep the balance be tween conditional tr aining with the disc iplinary approach and training in par tnership for mu ltidisciplinary programs.

This $p$ aper $d$ escribes th exa mple of corp orate e-l earning course for managers and to $p$ managers from a major telecommunication c ompany. Each module is de dicated to a concrete in terdisciplinary top ic d eveloped b y a $g$ roup of several tea chers. Practi cal $p$ art of th e modu le con sists of concrete $p$ roblems, which employees $h$ ave to $s$ olve while training.

Index Terms-Corporate e-learning c ourse, distance le arning, mixed training.

\section{INTRODUCTION}

Pedagogy, as the science of education, learning and human development, originates from the ideas of Demokrit (460 BC - $370 \mathrm{BC})$, Socrates (469 BC - $399 \mathrm{BC})$, Platon (427 BC - $347 \mathrm{BC}$ ) and Aristotle (384 BC - 322 $\mathrm{BC})$. Erasmus Roterodamus $(1465-1536)$ is considered the first teacher-humanist and John Amos Comenius $(1592-1670)$ is the first didact.

Recently classical pedagogy that is grounded on the didactics of Jan Komenský, has been dominated in the corporate training. According to classical pedagogy the tutor being the carrier of large volume of the systemized information transmitted this information to a trainee who had to master this considerable amount of already complete knowledge.

Past years the world faced a global competition in every kind of business. Corporations and companies started to lack for efficient corporate training which meets present time challenges and relies on modern pedagogical technologies, up-to-date information technologies and training network models. Classical pedagogy has been replaced by modern pedagogy of adult training that introduces a new educational paradigm aimed at a person and corresponds to the principals of humanization of training.

Below the paper describes the models of corporate system training.

\section{MODELS AND STRATEGIES OF CORPORATE TRAINING}

By the present two models of corporate training have been formed. The first model is founded on the so called "intercompany" training which takes place within the company only. This kind of training fully meets demands of the company and ensures a prompt reaction of pedagogical system to changes that occurred in the company. Among companies using this model of training are Alcatel-Lucent, Simens, Gasprom and etc. If the company doesn't own intercompany training recourses, then it has to apply to independent educational institutions. In this case training content is developed by the selected educational institution.

The second model of corporate training is founded on an autonomous educational institution, which offers own training programs and methods of training developed independently of the company as well as training programs developed on the company's demand and methods of training coordinated with the company. This model implies more independence for the educational institution when developing training content and choosing method of training. The autonomous training institution may render services to several companies and corporations. Among institutions successfully using this model are Stanford University [1] and Deutsche Telekom Hft Leipzig.

When organizing corporate training, it is important to determine the strategy of training properly (Fig. 1). On the one hand, the educational institution has to follow the market and be able to satisfy the demands of corporate clients and companies. It is a so called market adaptation.



Figure 1. Strategy development model of corporate training 
Such approach is typical of the first model of corporate training. However, this approach implies a number of shortcomings. An excessive interest in market adaptation may lead to lop-sided development of training process: the educational institution turns into the mirror reflecting the corporation opinion and moulds its vision of the future only due to demands of the corporation.

When choosing the strategy, the only adaptation skill is not enough even if the company's opinion is attentively considered. Peter Lorange states [2] that "it is very dangerous to amend the curriculum radically in response to another folly of the corporate management or change of market conditions (possibly temporary)".

In contrast to that, there can be an approach when the educational institution looks for relevant development strategies on its own leaving behind demands of the corporation and competitors. Such educational institution strives to be a leader in any changing preferences and to bring its strategy in conformity with future interests and requirements of the company. As Nirmalya Kumar and his colleagues deem [3], the educational institution has to become a pioneer in educational market. It is obvious that the leaders to meet in changing preferences are autonomous educational institutions, which have close corporative links with companies. It should be noted that the main point for the educational institution is to find a balance between adaptation and initiative and keep this balance. Thus the horizontal axis on Fig. 1 is called a direction of the balance search.

The development of balanced strategy of corporate training is considerably influenced by two forces. One force directed from below to upwards is a contribution of tutors from the educational institution to the development of strategy. Tutors' knowledge, professional experience and scientific researches that they conduct form competences of the educational institution and influence the strategic development of the educational institution.

The forces directed from below to upwards are supplemented with a corporative view of the problem from on high and with instructions to change the strategy of corporate training. The vertical axis on Fig. 1 is called the curve of participants involved in the process (or forces influencing the development of corporate training). It is clear that is in any point of time a real strategy of corporate training is a result of every factor's alterations and interconnection of all interested parties. To keep a dynamic balance of their influences is a very important task.

The best balance of forces influencing the development of corporate training is achieved in the second model because the independent educational institution has certain autonomy from companies and corporations and it conducts full-scale scientific researches. The dashed line on Fig. 1 divides the space of existence of the first and second models of corporate training. It is necessary to emphasize that the border between these models' spaces is not very accurate as it is showed on the picture. The border just underlines fundamental differences of the models.

Fig. 2 depicts the model of formation of methods and technologies of corporate training. The horizontal axis on Fig. 2, a defines the level of training's interactivity: from a total lack of interaction in conventional lectures to the highest degree if interaction in partnership or cooperation.
Traditional training is grounded on the disciplinary approach to training. However, today business faces complex problems which solution can be found at the joints of disciplines and activities. Companies need multidisciplinary approaches to training. Today modern and successful training programs are not based on mastering of single subjects but designed in modules when activities of various tutors are coordinated to the most degree. The vertical axis on Fig. 2, a depicts the interactivity degree of training programs: from discrete single programs to multidisciplinary modules. On this figure a dashed line divides spaces that belong to this or that model of corporate training. As before, a well-defined balance between conventional training with a disciplinary approach and multidisciplinary training in partnership is very important.

The model of corporate training technologies is showed on Fig. 2, b. The horizontal axis on the figure points at the range of applicable pedagogic technologies: from a conventional in-class training with a teacher, as the main character in of training process, to network selfdirected training, where the main object and subject of training is a trainee. The vertical axis on this figure depicts a range of applicable means of training process informatization: from a total lack of such means, when the main source of information is a teacher and a blackboard, to a complete set of information technologies: PC, multimedia, Web-servers and etc.

It is very important to develop modern training methods based on network technologies, in particular, internettechnologies, which allow implementing a new paradigm of education aimed at a person and appropriate to principals of humanization of education.

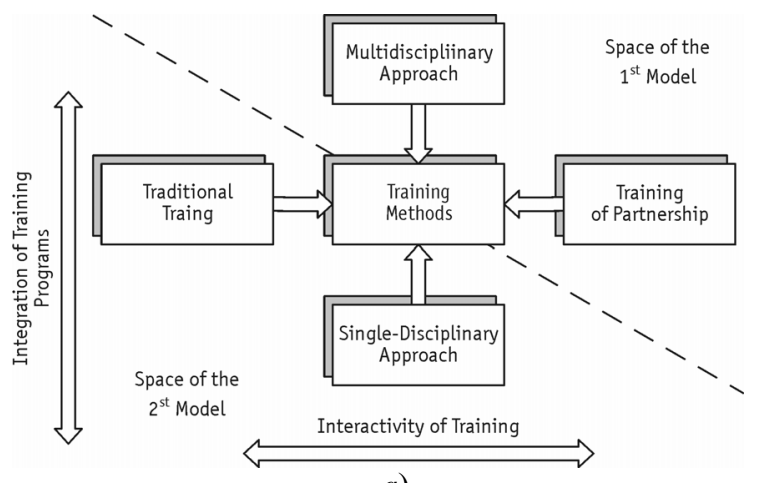

a)

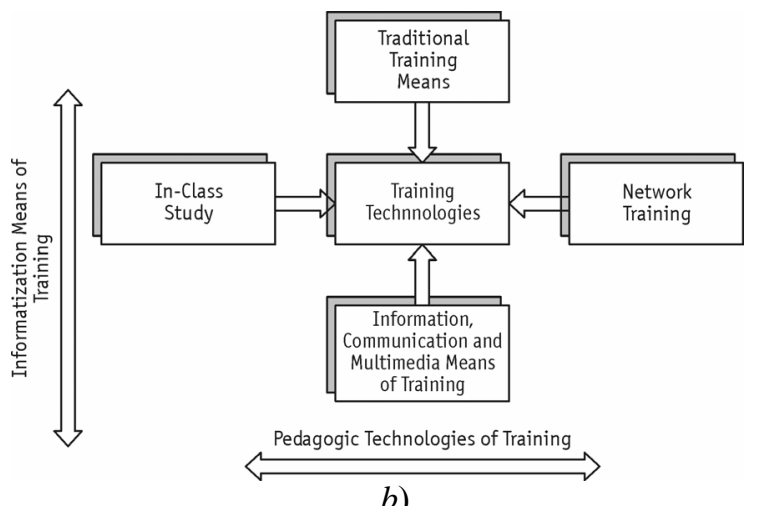

Figure 2. Model of formation: $a$ ) training methods; $b$ ) training technologies 


\section{Advantages and Pecularities of Distance LEARNING TECHNOLOGIES}

Today the methods of traditional training are being replaced by e-learning methods using computers and information technologies. It has become possible to deliver files with learning content to a big number of trainees; to provide a regular communication between trainees, their teachers and tutors; to access any information resources via Web-servers.

Not every company has an opportunity to let its employees to study face-to-face leaving their offices, therefore e-learning is the best kind of training of employees for companies.

The opportunity to study while at work and remain in one location with no need to travel is very urgent for the employees who live in remote towns or villages.

The main motivations for people working in the Internet are wish to get brand new information and communicate with qualified specialists; convenience in sharing emails and software; compensation for various communication barriers. Approximately a half of respondents $(52 \%)$ is advanced PC users and has a positive attitude towards e-learning, only $20 \%$ of respondents are against e-learning, but the older a trainee is, the better attitude towards e-learning he or she has. Recent world researches in e-learning exposed that $80 \%$ of trainees can efficiently perceive learning information in any form. It means that the majority can learn electronically via the Internet. According to the USA company employee poll, $85 \%$ of the employees surveyed prefer to study during their working time and $62 \%$ prefers to study in office.

One may speak about many advantages of e-learning, however we'll try to formulate the main of them which considerably influence the company's activities.

1. Instructors and recognized experts can be easily attracted to the learning process. They can share their knowledge across borders.

2. High-efficient learning material can be developed by help of high-qualified tutors and industry experts without bringing them on the staff.

3. Employees may remain in one location (e.g., home, office).

4. The company reduces costs for business trips (transport, accommodation, meals).

The peculiar features of corporate training put certain requirements on the training process. The most important methods of training are interactive lectures, discussion groups, trainings, role playing and computer simulation. The most powerful didactics means in the system of corporate e-learning can be tele- and videoconferencing, which allow organizing public discussions of various issues, delivering lectures over large distances, sharing opinions and thereby, eliminate trainees' feelings of absolute isolation. A very important characteristic and peculiarity of e-learning is interactivity. It can be interaction among the teacher (tutor) and the student, between separate students and student groups. Introduction of interactivity in e-learning help supporting a human ability to self-learning at a very high level. The use of multimedia makes learning process visual and creates trainee's motivation to study learning material. Such technologies enable observing dynamics of various processes in devices,

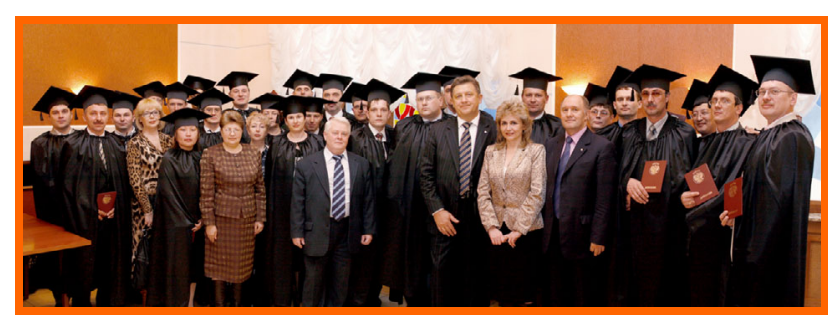

Figure 3. The trainees from the telecommunication company "Sibirtelecom" and teacher's team

circuits and technologies, which is very important for telecommunication industry.

The information technologies listed above allow creating electronic information educational environment [6] where electronic learning materials work well: electronic textbooks, PC learning software, electronic sets for selfcontrol and obtained knowledge monitoring, simulators which help the trainee to improve certain professional skills. Business, situational and simulation games play important part in e-learning.

\section{EXAMPLE OF CORPORATE LEARNING COURSE TO TRAIN TELECOMMUNICATION COMPANY PERSONAL}

This section describes the example of the corporate elearning course developed by the Siberian State University of Telecommunications and Information Sciences on the basis of the models of corporate training organization for managers and top managers from the telecommunication company "Sibirtelecom" that provides the whole range of modern telecommunication services in the Siberian Federal District (Fig. 3).

First of all, a balanced training strategy has been determined. On the one hand, in compliance with the company's demand the course includes traditional disciplines and topics such as Strategic Management, Strategic Marketing, Financial Management and Resource Management. On the other hand, the University proposed to include burning topics for the company's active functioning on the market as Change Management, Risk Management and efficient management tools of the company's activity as BSC (Balanced Scorecard), CRM (Client Relations Management), Controlling and other topics widely used among world-known companies.

In order to determine pedagogic technologies of training in compliance with the model of corporate training technologies proposed in the paper, the organizers of corporate training adhere strictly to the balanced strategy grounded on the use of blended learning. Each of five modules involves an e-learning part based on the Internet technologies (96 hours) and a classroom training part (24 hours). Introduction of network training technologies into the corporate course allows using all advantages of e-learning described in the paper. The trainees communicate with each other and teachers receive feedback from trainees via e-mail, forums and conferences built-in the module.

The content of every module is dedicated to a concrete interdisciplinary topic developed by the teachers specialized in different disciplines and related to the trainees' professional activities.

On the main page of the course the trainee may look through the course curriculum, get information about the trainers, learn training news on public bulletin board; 
leave a message in the guestbook, go to a necessary module.

To let trainees make the acquaintance of the trainers, the system of "visit cards" with pictures is used (Fig.4).

While mastering the module, trainees communicate to the trainers, other trainees and company experts via email built-in the module.

In accordance with the model of training methods formation, the course involves such interactive methods as practical trainings, project development and working in small groups. The practical tasks proposed to the trainees include specific problems of the company, for example: development of business process models, financial analysis of efficiency of telecommunication service sales, design of the company's marketing policy, calculation of cost price and price rate of ADSL service and etc.

The trainees' survey testified to the success of the described corporate e-learning course (Table 1).

The trainees meet each other and form a training team on the introduction forum.

The course implementation has been positively evaluated and considered successful both by managers and head officials of the company. About $40 \%$ of managers, who took the course, have been promoted in the "Sibirtelecom" telecommunication company.

\section{REFERENCES}

[1] C.M. Lee, W.F. Miller, M.G. Hancock, H.S. Rowen, "The Silicon Valley Edge: A Habitat for Innovation and Entrepreneurship", Standard, CA: Stanford University Press, 2000.

[2] P. Lorange, "New Vision for Management Education: Leadership Challenges", Pergamon, 2002.

[3] N. Kumar, et al. "From Market Driven to Market Driving", European Management Journal, p. 129-142.

[4] B.I. Krouk ,S.G. Sitnikov, "Intergovernmental DL Training Center in Telecommunications, Information Technologies, Economics and Business for CIS Countries", Human resource development quarterly. ITU. 2002. № 88.

[5] B.I. Krouk, O.B. Zhuravleva, "Distance Learning Program to Raise Skills of Managers from Russian Telecommunication Enterprises”, IEEE Communications Magazine. 2004, Vol. 42. № 5.

[6] B.I. Krouk, O.B. Zhuravleva, "Internet-training Management in Universities" Editor prof. B. Krouk, Moscow: Publishing House "Hotline-Telecom", 2007.

\section{AUTHORS}

S. G. Sitnik ov is with the Siberian State University of Telecommunications and Information Sciences, Novosibirsk, Russia (e-mail: sgs@sibsutis).

B. I. Kruk, is with the Siberian State University of Telecommunications and Information Sciences, Novosibirsk, Russia (e-mail: krouk@sibsutis).

O. B. Sitnikov is with the Siberian State University of Telecommunications and Information Sciences, Novosibirsk, Russia (e-mail: zhuravleva@sibsutis).

N. A. Chup akhina, is with the Siberian State University of Telecommunications and Information Sciences, Novosibirsk, Russia (e-mail: nash@sibsutis).

Submitted October $1^{\text {st }}, 2010$. Published as resubmitted by the authors October $17^{\text {th }}, 2010$.

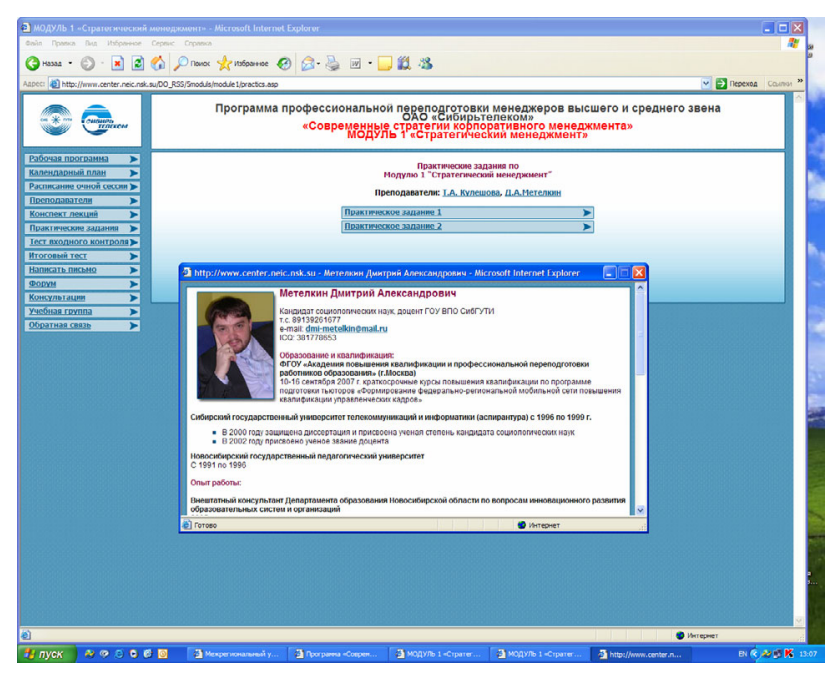

Figure 4. "Visit card" of a teacher

TABLE I.

SURVEY QUESTIONS AND SUMMARY OF RESPONSES

\begin{tabular}{|c|c|}
\hline $\begin{array}{c}\text { Questions to evaluate the level of the course } \\
\text { organisation }\end{array}$ & Average result \\
\hline $\begin{array}{l}\text { 1. How would you rate the quality (user-friendly, } \\
\text { connection) of the Distance Learning (DL) website } \\
\text { and access to information on the website? }\end{array}$ & 4,43 \\
\hline $\begin{array}{l}\text { 2. How would you rate the user friendliness of the } \\
\text { DL website? }\end{array}$ & 4,48 \\
\hline $\begin{array}{l}\text { 3. How would you rate the usability of the overhead } \\
\text { information (public bulletin boards, software, } \\
\text { training schedules, visit cards, timetables of consul- } \\
\text { tations and etc.) }\end{array}$ & 4,84 \\
\hline $\begin{array}{l}\text { 4. How would you rate the quality of lectures (con- } \\
\text { tent, easy to understand, available examples, self- } \\
\text { control questions)? }\end{array}$ & 4,57 \\
\hline $\begin{array}{l}\text { 5. How well did the practical part of the course } \\
\text { contribute to a better understanding of training } \\
\text { materials? }\end{array}$ & 4,62 \\
\hline $\begin{array}{l}\text { 6. How well were your knowledge and skills con- } \\
\text { trolled? }\end{array}$ & 4,43 \\
\hline $\begin{array}{l}\text { 7. How well did the means of self-control contribute } \\
\text { to a better understanding of training materials? }\end{array}$ & 4,15 \\
\hline 8. How well did you learn from the trainer? & 4,62 \\
\hline 9. How would you evaluate the "module" format? & 4,49 \\
\hline $\begin{array}{l}\text { 10. How did you feel about communicating with } \\
\text { other trainees (your colleagues)? }\end{array}$ & 4,9 \\
\hline $\begin{array}{l}11 . \text { How would you rate the feedback of the course } \\
\text { administration? }\end{array}$ & 4,62 \\
\hline $\begin{array}{l}\text { 12. How did you feel about discussing problems on } \\
\text { the forum? }\end{array}$ & 4,79 \\
\hline $\begin{array}{l}\text { 13. How well did the course contribute to obtaining } \\
\text { of new knowledge and skills? }\end{array}$ & 4,29 \\
\hline $\begin{array}{l}\text { 14. How well did the course contribute to accom- } \\
\text { plishment of your professional duties? }\end{array}$ & 4,71 \\
\hline
\end{tabular}

